\title{
Demographic Change and Private Savings in India
}

\section{Neha Jain ${ }^{1}$ and Srinivas Goli2*}

1. Assistant Professor of Economics, Indian Institute of Foreign trade (IIFT), New Delhi, India. Email: 9ruls4.neha@gmail.com.

ORCID: https://orcid.org/0000-0002-8755-9741

2. Australia India Institute, New Generation Network Scholar, The University of Western Australia (UWA)

\& Assistant Professor, Population Studies in Centre for the Study of Regional Development (CSRD), School of Social Sciences (SSS), and Jawaharlal Nehru University (JNU), India,

$\mathrm{T}+6186488$ 2914, M +61 41`6271232.

Email: srinivas.goli@uwa.edu.au

ORCID: http://orcid.org/0000-0002-8481-484X

*Corresponding author: srinivas.goli@uwa.edu.au

\section{Acknowledgements}

We would like to thank Prof. K. S. James, Director of International Institute for Population Sciences (IIPS), Prof. P. M. Kulkarni, former Professor at the Centre for Study in Regional Development (CSRD), Jawaharlal Nehru University (JNU), New Delhi, and Prof. Anu Rammohan and other colleagues at the Economics Department, UWA Business School, The University of Western Australia, Perth for a number of fruitful discussions and their insightful comments on the topic. 


\title{
Demographic Change and Private Savings in India
}

\begin{abstract}
India is on the edge of a demographic revolution with a rapidly rising working-age population. For the first time in this study, we investigate the role of the rising working-age population on per capita small savings in post offices and banks net of socio-economic characteristics using state-level panel data compiled from multiple sources for the period 2001-2018. Our comprehensive econometric assessment with multiple robustness checks provide three key findings: (1) Per capita private savings is increasing because of India's growing working-age population, thus the 'economic life cycle hypothesis' is evidentially supported. (2) The demographic factors contribute around one-fourth of the per capita private savings inequality across Indian states. (3) The demographic window of economic opportunity for India can yield maximum benefits in terms of private savings when accompanied by favourable socio-economic policies on education, health, gender equity, and economic growth.
\end{abstract}

JEL Classification: J11, 015, O16

Keywords: Demographic change, Working age population, Population Ageing, Private savings, Life cycle hypothesis, Econometric analyses 


\section{Highlights}

- India's growing working-age population is positively associated with higher private savings and supporting 'economic life cycle hypothesis'.

- The demographic factors are contributing around one-fourth of the inequality in per capita private savings across states.

- The 'demographic window of opportunity' for India can yield higher private savings when accompanied by favourable socio-economic policies. 


\section{Introduction}

Despite receiving a considerable attention from economists and economic demographers globally, there is hardly any evidence on the impact of demographic change on private savings in India. Over the last five decades, the 'dependency hypothesis' by Coale and Hoover (1958) and the 'life cycle hypothesis of savings' by Modigliani and Brumberg (1954) are considered as pioneering analytical frameworks in understanding the relationship between the change in age distribution of the population and savings. Both hypotheses simply assert that the 'age-saving' profile show a humped graph; that is, higher savings during the working age and lower savings at young and old ages. Stated differently, the working age population serves as a catalyst for promoting economic growth through savings (Loayza, Schmidt-Hebbel, \& Serven, 2000a, 2000b; Lee, Mason, \& Miller, 2000; Mason, 1988; Masson, Bayoumi, \& Samiei, 1998; Mason \& Kinugasa, 2008; Mason, Lee, \& Jiang, 2016). Based on these hypotheses, for the first time, this paper seeks to undertake an econometric assessment of the nexus between demographic changes and the private savings ${ }^{1}$ for India, drawing on a panel of major states for the period 2001-2018.

India is experiencing a 'demographic revolution' with a shift towards the working-age group in age structure of the population relative to the population of dependents (child and old age population). Figure 1 illustrates the age-structural transition of the Indian population (19512100). Its share of the working age population has increased from approximately 58 per cent in 2000 to reach a maximum of approximately 65 per cent in 2035 . The size of child population is continuously falling whereas the share of the older-age population is rising slowly due to improvement in life expectancy. In 2020, the average age in India was 29 years while in the USA, Europe, and Japan, for instance, it was 40 years, 46 years, and 47 years respectively (National Policy for Skill Development and Entrepreneurship Report, 2015). Since young people tend to save more, a substantial impact on private savings in India is expected.

Besides, there are huge inter-state variations in the process of demographic transition in India, which can exert influence on the private saving pattern and such heterogeneity makes an ideal setting to test our hypothesis. Figure 2 highlights the trends in the share of working age population across major states of India for the period 2001-2016. It can be seen that the share of working age population is rising across all major states of India. Some states from south and

\footnotetext{
${ }^{1}$ Private savings is defined as gross small savings collection in post offices and banks provided by National Savings Institute, Ministry of Finance, Government of India. These schemes commenced in 1882 with the establishment of Post Office Savings Bank in India. The main purpose of the scheme was to inculcate a habit of saving among all sections of the society and to mobilise resources for capital formation, economic growth and development in the country. It has been a vital source of financial savings of households in the country due to its safe and secure nature of investment (as they are liabilities of the central government), offering better returns than other saving products in the market along with tax benefits, etc. The significance of these schemes have enhanced over time with structural changes in the Indian economy, greater financial inclusion with bank nationalization, opening up of post offices and bank branches throughout the country, better financial sector safety, provision of social security through numerous schemes of the government such as NREGA, old-age pension schemes, etc. Small savings schemes are carried out by a nationwide network of 1.5 lakh post offices, majority of which are located in remote parts of rural areas and which help in boosting formal financial savings in these regions through small savings schemes (Report of the Committee on Comprehensive Review of National Small Savings Fund, 2011).
} 
west India will find their demographic dividend phase closing in next few years due to early decline in fertility levels while the window of opportunity is yet to commence in high fertility states like Bihar, Jharkhand, Madhya Pradesh, Rajasthan, and Uttar Pradesh.

Figure 1. Age-composition of India's Population (1951-2100)

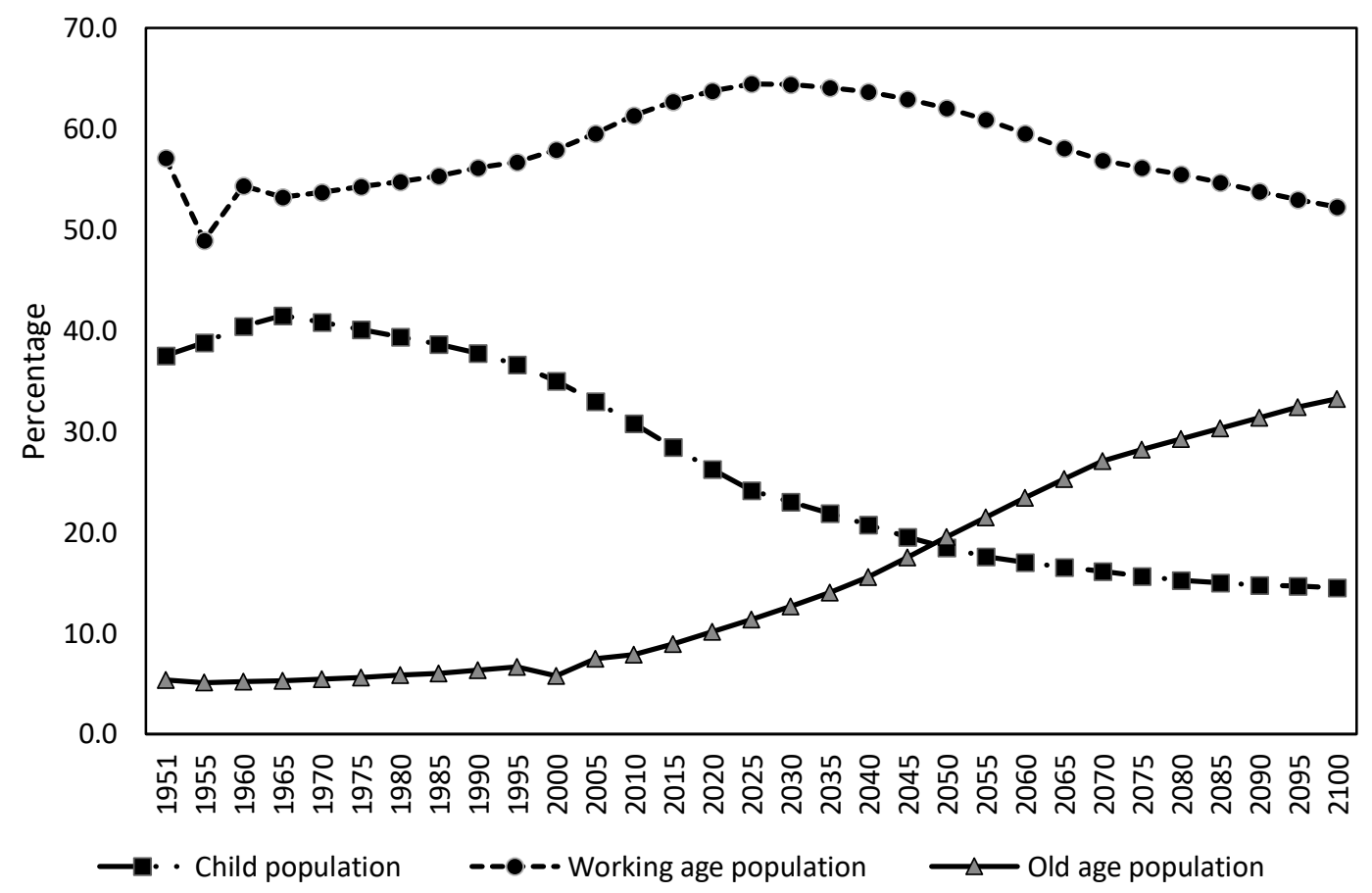

Source: World Population Prospects (19th Revision), United Nations 2019.

Figure 2. Trends in the Working Age Population Share across Major Indian States (2001-2016)

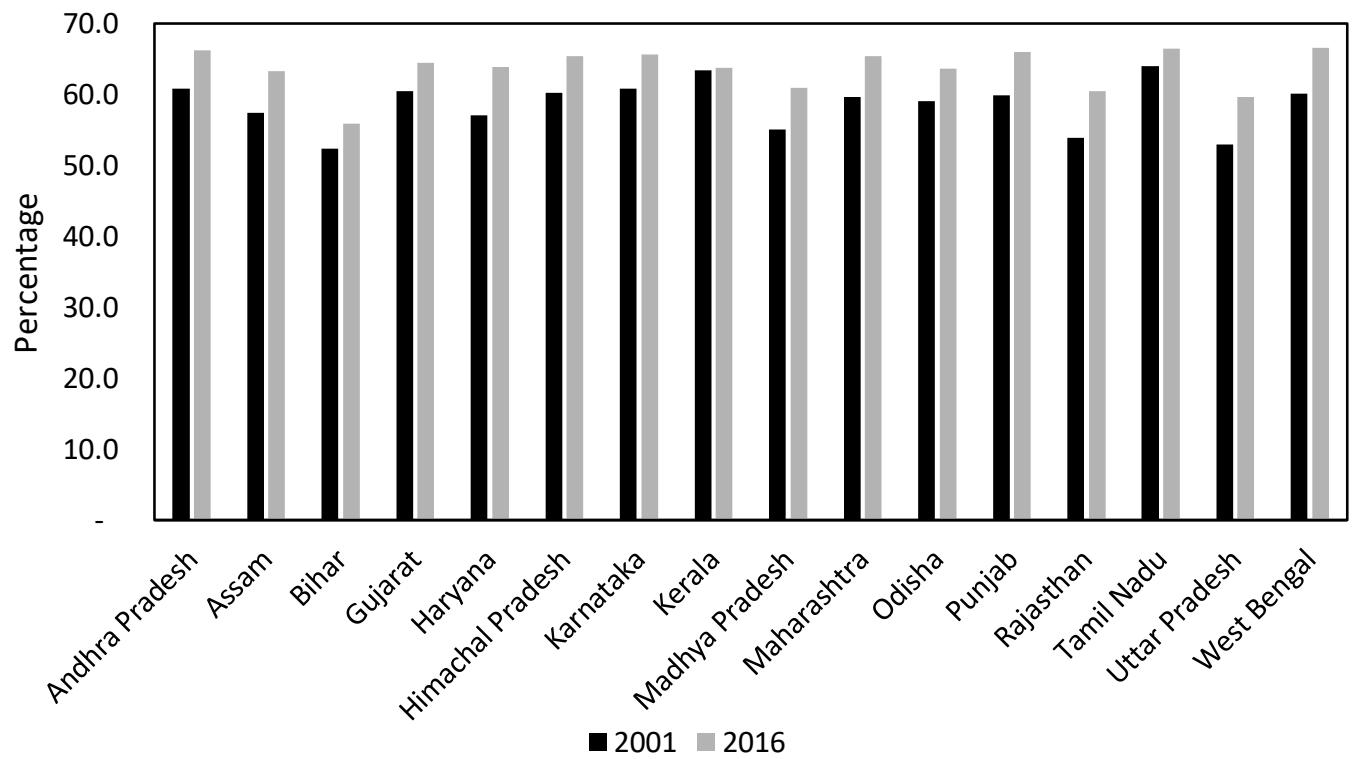

Source: Census of India, Office of the Register General India. 
The empirical results of the impact of age structure on savings based on cross-country panel data and time series data from individual countries have been ambiguous. Some studies, in line with the life-cycle and dependency hypotheses, have suggested that a rise in the share of dependents (both young and old) tends to reduce savings level (Ahmad, 2002; Akhtar, 1986; Ali, Ahmad, \& Butt, 1997; Burney \& Khan, 1992; Dayal-Ghulati \& Thimann, 1997; Fry \& Mason, 1982; Heller, 1989; Higgins \& Williamson, 1997; Horioka, 1997; Hurd, 1996; Kelley \& Schmidt, 1996; Khan, Hasan, \& Malik, 1992; Leff, 1969; Loayza et al., 2001a; Mason, 1988; Modigliani, 1970; Pryor, 2003; Thornton, 2001; Uremadu, 2009; Yasin, 2008). While others have found little evidence of a significant relation between the dependency ratio and savings (Adams, 1971; Gersovitz, 1988; Goldberger, 1973; Gupta, 1971; Ram, 1982, 1984; Rossi, 1989; Shumaker \& Clark, 1992). Studies by Curtis, Lugauer and Mark (2017), Higgins and Williamson (1997), Higgins (1998), Horioka and Hagiwara (2010), Kim and Zang (1997), Park and Shin (2009), Schultz (2004), Shumaker and Clark $(1992)$ and Ram $(1982,1984)$ have empirically tested this relationship for a global sample of countries, including India, covering various years from 1970 to 2007 and found a mixed impact of population age structure on savings for India.

\subsection{Main Contributions of the study}

This study makes five major contributions: First, previous studies based on India have analysed the relationship of age structure and savings for the period before 2000 while the onset of the 'demographic window of opportunities' for India was in 2005-06. Thus, it is important to document evidence on the relationship of population age structure and savings for the period after its onset. Second, this is the first study that employs state-level panel data of per capita private saving collections in post offices and banks, provided by the National Savings Institute, Ministry of Finance, Government of India, to study its relationship with demographic changes in the country. Third, the study controls for a range of key socio-economic variables to estimate a net demographic effect on private savings. Fourth, an interaction analysis of the demographic change with key socio-economic covariates is carried out to ascertain whether the influence of working age population on the private savings is conditioned by the socio-economic environment of the country. Finally, following the framework proposed by Loayza et al. (2000a, 2000b), the reliability of the basic results is verified by using multiple robustness tests along two dimensions: First, we employ alternative econometric techniques: (1) For the first time, we use regressionbased inequality decomposition model to estimate the contribution of demographic differences to inequality in per capita private savings across Indian states. (2) We consider there is a possibility of endogeneity in the relationship between the working age population and savings, as its impact on savings operates through the channels of education, health, gender equity and economic growth. Also, growth in per capita income is likely to be jointly determined with savings through the saving-investment link. Thus, the instrumental variable model (two-stage least 
square) is employed to assess the endogeneity issue. Second, we use an alternative sample to check the baseline result.

Our primary objective is to answer three questions: (1) How much of the impressive increase in private savings in India can be explained by its increased working age population? (2) How much of the inter-state inequality in private savings can be explained by differences in the level of working age population across the states and over time? (3) What are the possible channels through which the increasing working age population can influence private savings?

The summary of the findings based on analysis of 16 major states of India for the period 20012018 using multiple econometric methods, such as panel data regression model, regressionbased inequality decomposition model, and instrumental variable regression (two-stage least square) is reproduced below.

First, our results confirm the life cycle hypothesis that larger working age population leads to a rise in the savings. According to fixed effects estimation, a one percent rise in the working age population raises private savings by nine percentage points, other factors being constant. Second, demographic factors explain around one-fourth of the per capita private savings inequality across states after controlling for other core policy variables. Third, the demographic window of economic opportunity for India could result in higher per capita private savings if favourable socio-economic policy environment such as healthy and educated working age population, higher gender equity, and a higher level of per capita income is in place.

The rest of this paper is organised as follows. Section 2 provides a literature review. Section 3 deals with the empirical strategy, including data and descriptive, and empirical specifications. Section 4 discusses estimation results and conducts numerous robustness checks. Section 5 concludes the paper.

\section{Literature Review}

Since the inspiring work of Coale and Hoover (1958), long-term economic analysis of savings has been focusing on demographic changes by way of a simple and strong 'dependency hypothesis' which states that a higher dependency burden would result in higher consumption expenditure and lower savings rate. Over time, young dependents would mature to become the working age population and a higher savings rate will result. Finally, savings would decline with the demographic transition moving towards increasing elder dependents.

Another theoretical framework for understanding the relationship between demographic structure and savings is the 'life cycle hypothesis' (Modigliani \& Brumberg, 1954), according to which increasing working age population may escalate the aggregate savings of the economy, as, at first sight, it naturally implies an increase in the size of productive workforce that produces more than it can consume relative to the very young and the elderly population which consumes more than it produces (that is, it dis-saves). Secondly, a fall in the dependency ratio induced by the lower fertility rate and slower population growth lead to a greater participation of females in the labour market, in turn raising the per capita productive capacity of the economy. In addition, 
households with fewer children and elderly could save the expenditure incurred for the dependent's care and allows them to make a greater investment in their health and education, which over time improves their life expectancy and further compels people in the working age to save more for their retirement (Bloom \& Williamson, 1998; Bloom, Canning, \& Sevilla, 2003; Bloom, 2011; Modigliani \& Brumberg, 1954).

Based on these theoretical grounds, empirical estimation of the impact of age structure on savings was first attempted by Leff (1969) and Modigliani (1970), who found a strong negative relation between the dependency ratio (the ratio of young and old to the working age population) and aggregate savings in less developed countries. However, subsequent empirical analysis by Adams (1971), Gupta (1971), Goldberger (1973), Ram (1982, 1984), Gersovitz (1988), Rossi (1989), and Shumaker and Clark (1992) criticized Leff's original work (1969) because of the way the data handled and variables specified as well as sample composition, and estimation methods, and found an insignificant impact of dependency on savings in the Third world countries.

Further studies based on individual countries' time series and panels of cross-country data revealed a mixed impact of age structure on savings. For instance, studies by Akhter (1986), Burney and Khan (1992), Khan, Hasan and Malik (1992), and Ahmad (2002) found a negative relation between dependency ratio and savings in Pakistan. The life cycle hypothesis was supported by Kelley and Schmidt (1996) for 89 countries during the 1960s to 1980s and by Horioka (1997) for time series data of Japan by applying the co-integration techniques. Higgins and Williamson (1997) estimated this relationship for 16 Asian countries (including India) for the period 1950 to 1992 and explained the East Asian Miracle by linking the opening of a window of economic opportunity that resulted in higher savings and economic growth rates (Bloom \& Williamson, 1998; Birdsall, Kelly, \& Sinding, 2003; Mason, 2001). Later the study by Schultz (2004) re-estimated the same relationship by taking the same sample and time frame and found insignificant results after considering lagged savings as endogenous.

One of the earlier estimates for India by Higgins (1998) found that India's demographic changes remained stable and increased savings by only 1.8 percentage points between 1965-69 and 1985-89. The negative impact of dependency on private savings was found by Dayal-Ghulati and Thimann (1997) for a sample of Southeast Asian and Latin American countries over the period 1975-95 and by Loayza et al. (2000a) using World Bank data on savings for 150 countries for a period of 1965 to 1994. Thornton (2001) found similar results for the US by applying cointegration techniques to annual time series data for the period 1956-1995. Yasin (2008) tested the life cycle hypothesis for fourteen emerging markets for the period 1960-2001 and found a significant positive relationship between the savings ratio and percentage of the working age population. Park and Shin (2009) study estimated this relationship for eight countries (including India) between 1970 and 2005 and found that dependency (both aged and young) had a negative impact on the saving rates. Uremadu (2009), however, for the period 1980-2004 did not find a significant impact of demographic factors on the savings ratio in Nigeria despite a high 
dependency ratio of the population. Horioka and Hagiwara (2010) found aged dependency ratio, income levels, and the level of financial development as important predictors of the domestic saving rates in Asia (including India) during 1966-2007. Curtis, Lugauer, and Mark (2017) is the latest study in this context for India, China and Japan covering the period 1970 to 2007 . The study confirmed the life cycle hypothesis using the preferences model from Barro and Becker (1989) for all three countries. They found that India's rising working age population along with smaller family size has resulted in higher household savings rate; they also projected the higher saving rates to continue in the future. Another recent study by Hu, Lei, and Zhao (2020) based on a panel data of 172 countries for the period 1960 to 2019 also confirmed the life cycle hypothesis by showing that a one percent rise in the share of elderly population reduces the aggregate saving rates by 1.04 percent.

Summing up, the empirical estimation of the link between age structure and savings is ambiguous regarding both direction and magnitude across different countries and time frames. This study does a fresh investigation of this relationship for India by employing robust econometric models based on state-level panel data for the period 2001-2018.

\section{Empirical Strategy}

\section{Data and Variables Description}

The data used here is compiled from widely acceptable and reliable sources for 16 major states of India ${ }^{2}$ for the period 2001-2018. A stacked time-series balanced panel data is constructed for 16 states $\times 2$ time points, thus for a total of 32 cases.

Outcome variable: The per capita gross private saving collections in post offices and banks obtained from the National Savings Institute, Ministry of Finance, Government of India ${ }^{3}$ are considered as the outcome variable. As per the annual report on analysis of trends of small savings collections (2017-18), gross private saving collections in post offices and banks during 2017-18 were around five lakh crores, registering an annual impressive growth of 19.18 per cent compared to the preceding year. Out of the total gross collection in 2017-18, around 82 per cent was contributed by post offices with a remaining share contributed by the authorized commercial banks. Figure 3 highlights the trends in the state-wise per capita gross private small savings collections in post offices and banks during 2001-02 to 2017-18. It shows that there has been a significant increase in per capita gross collections across all the states during the period considered. The highest surge in gross collections has been found in Himachal Pradesh, followed by Odisha, Kerala, Karnataka, West Bengal, Andhra Pradesh, and Maharashtra in that order.

\footnotetext{
2 The states included are Andhra Pradesh, Assam, Bihar, Gujarat, Haryana, Himachal Pradesh, Karnataka, Kerala, Madhya Pradesh, Maharashtra, Odisha, Punjab, Rajasthan, Tamil Nadu, Uttar Pradesh, and West Bengal.

${ }^{3}$ http://www.nsiindia.gov.in/internalpage.aspx?Id_Pk=153
} 
Figure 3. Trends in Per Capita Gross Private Small Saving Collections in Post Offices and Banks (2001-2018)

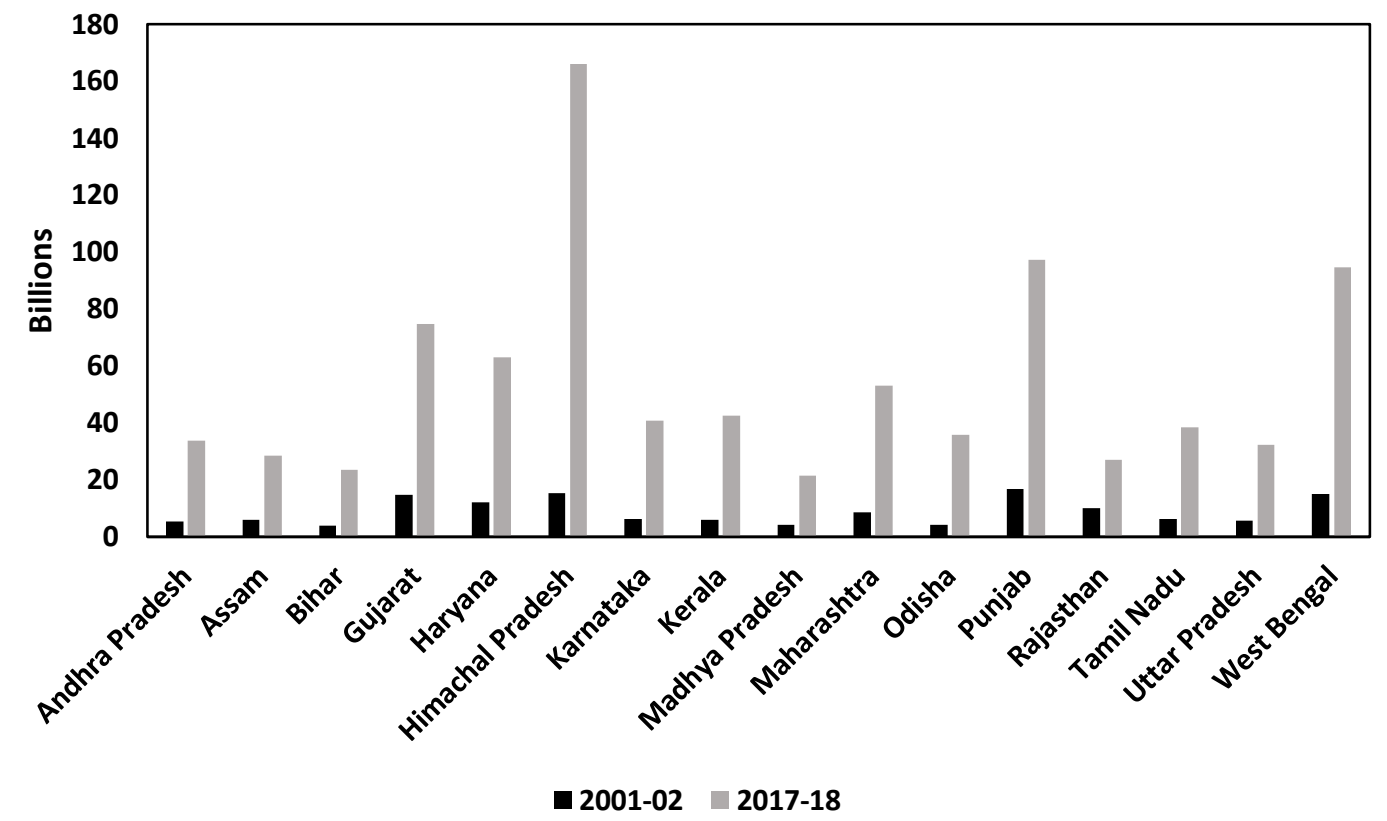

Source: National Savings Institute, Ministry of Finance, Government of India

Explanatory variables: The working age population ratio (15-59 years) taken from the Census of India in percentage is considered as the main predictor variable of savings. Besides, other covariates are taken to have a net demographic effect on private savings. These are social sector expenditure, governance index, wealth inequality, farm GSDP share, female-headed households, rural inflation, urban inflation, literacy rate, post office density, bank density, gender development index, gender empowerment measure, life expectancy, log per capita income, growth in per capita income and mean monthly per capita consumption expenditure (MPCE). The selection of these explanatory variables is premised on the existing research and a theoretical rationale. Below we discuss specific definitions of each of these control variables.

Social sector expenditure: Social sector expenditure comprises of the expenditure on education, healthcare and rural development by the government as a percentage of GSDP. There is no previous study which has considered the effect of social sector expenditure on savings. We expect that it may boost private savings by reducing out-of-pocket expenditure of families.

Governance index: The governance index captures five areas, namely, infrastructure, social services, fiscal performance, justice, law \& order, and quality of the legislature. This is expected to promote private savings as the better the quality of delivery of core public services, the higher is the emergence of "development clusters" (Mundle, Chowdhury, \& Sikdar, 2016). 
Wealth inequality: Theoretically and empirically, the effect of wealth distribution on savings is ambiguous (Loayza et al., 2000a). On the one hand, higher wealth inequality can promote savings as households with higher wealth tend to have a higher propensity to save than households with lower wealth. On the other hand, it can lower aggregate savings due to relatively lower savings by lower and middle-class wealth holders and the tendency of higher consumption by rich people.

Farm GSDP share: The share of the farm sector in GSDP is another relevant factor affecting savings. The statistical evidence on this relationship has been mixed. On the one hand, a decline in the share of the farming sector is an important factor for the rise in savings in India after the 1970s, since the marginal propensity to save of the farming sector is lower than that of the nonfarm sector (Krishnamurty \& Saibaba, 1981; M“"uhleisen, 1997; Rakshit, 1983). On the other hand, one may expect a higher marginal propensity to save in the farming sector than in the non-farm sector based on the permanent income hypothesis, which conjectures a higher marginal propensity to save out of transitory income. The studies by Athukorala and Sen (2004) and Samantaraya and Patra (2014) did not find a statistically significant influence of share of agriculture on savings in India.

Female-headed households: Several studies have estimated the impact of female-headed households on poverty in India. It is often argued that female-headed households face socioeconomic gender discrimination in education, income, rights, and economic opportunities (Dreze \& Srinivasan, 1997; Gangopadhyay \& Wadhwa, 2003; Meenakshi \& Ray, 2002; Rajaram, 2009). This makes an important case to check their impact on private savings.

Rural and urban inflation: The impact of inflation on private savings is indefinite. On the one hand, inflation could promote savings through income redistribution, real balance effects, and precautionary motive. Under the real balance effect or real wealth effect, consumers try to maintain a target level of wealth relative to income (as inflation depresses the value of real wealth) which reduces their consumption and raises savings. Further, with increased macroeconomic volatility (say, changes in future policies), people save a greater portion of their income as a precaution (Athukorala \& Sen, 2004; Dayal-Ghulati \& Thimann, 1997; Krishnamurty \& Saibaba, 1981; Loayza et al., 2000a, 2000b; Samantaraya \& Patra, 2014). Also, rural people tend to save more with inflation than urban, since income prospects in rural areas are much more uncertain and there is a lack of financial markets penetration for risk diversification (Loayza et al., 2000a). While on the other hand, in a country like India, where consumption levels are relatively low, consumers can resist cutting into real consumption and this could have negative effects on savings. Therefore, the ultimate impact of inflation would depend upon the magnitude of inflation (for instance, a very high inflation rate discourages growth and hence savings), the 
composition of consumption basket (durables and non-durables) and savings portfolio (physical and financial assets), future expectations, rate of interest, etc. (Krishnamurty \& Saibaba, 1981).

Literacy rate: Literacy rate is a new variable which no previous study has controlled so far to examine its effects on savings. It is expected to augment private savings as a literate person can make informed choices to manage income and resources. It can be taken as a proxy indicator for financial literacy.

Post office density and bank density: The level of financial development is an important determinant of private savings (Athukorala \& Sen, 2004; Dayal-Ghulati \& Thimann, 1997; Horioka \& Hagiwara, 2010; Loayza et al., 2000a, 2000b; Park \& Shin, 2009). We have taken two measures of financial depth: (1) Post office density, that is, population served by a post office. It helps in boosting formal financial savings through the network of 1.5 lakh post offices, with a majority of them located in remote parts of rural areas (Report of the Committee on Comprehensive Review of National Small Savings Fund, 2011). (2) Bank density, that is, distribution of scheduled commercial banks divided by the population of a state. This is expected to contribute significantly to rise in private savings.

Gender development index (GDI) and gender empowerment measure (GEM): Gender equality by way of investment in women's health, education, and economic opportunities can be one of the most powerful indicators of economic growth and hence savings. The present study analyzes the link between gender equality and private savings through two effective instruments of gender equity: GDI and GEM. GDI measures gender gap in health, knowledge and standard of living while GEM captures female participation in political and economic areas, and the power they have over economic resources (Report on Gendering Human Development Indices, 2009).

Life expectancy: An increase in life expectancy increases the post-retirement period of an individual and hence a given income is to be stretched for a longer time horizon. This leads to a rise in savings in all periods of an individual's life (Krueger, 2004; Park \& Shin, 2009).

Income: The basic life cycle hypothesis relates savings with the growth of per capita income, not the level of per capita income, as it assumes individuals are forward-looking and hence make private savings decisions based on lifetime income rather than current income. A growth of per capita income raises the lifetime resources of an individual, particularly of young relative to that of elderly and thus unambiguously increases the savings (Modigliani, 1970). Besides, it increases the number of households above the subsistence level of income, below which they are unable to save, which makes them more sensitive to interest rate changes (Ogaki, Ostri, \& Reinhart, 1996). However, in less developed countries like India, where a section of the population survives 
at the starvation level (that is, having low per capita income) cannot shift resources for later consumption. For such people, savings would increase with income level for a given growth rate (Athukorala \& Sen, 2004; Modigliani, 1970). Hence, both the (log) level of income and growth in income are considered in the present analysis and expected to have a positive effect on the private savings as suggested by other studies (Athukorala \& Sen, 2004; Dayal-Ghulati \& Thimann, 1997; Horioka \& Hagiwara, 2010; Loayza et al., 2000a, 2000b; Modigliani, 1970).

Mean monthly per capita consumption expenditure (MPCE): Mean MPCE is taken as a proxy for the income variable as income estimates are often underreported. Thus, MPCE can be taken as an indirect monetary measure in assessing the well-being of an individual. We expect it to be positively related to savings, at least for those individuals who are above the subsistence level of living. This means the higher the consumption expenditure, higher the propensity to save.

The descriptive statistics presented in Table 1 shows that the average per capita gross private savings is rupees 3,167 crores with its value ranging from rupees 407 crore to rupees 16,599 crore, demonstrating glaring disparities in per capita private savings across the states over time. Similarly, the main variable of interest, that is, the working age ratio also varies from 52.4 per cent to 66.5 per cent across the states over time. Other covariates too display stark differences in their value.

The Appendix table A1 shows the correlation matrix for the pooled sample from 2001 to 2018. It is evident from the table that the log of working age share is highly correlated with the log per capita private savings (the correlation value is 0.70 ). Other significant correlates of the per capita private savings are level of per capita income, growth in per capita income, bank density, GEM, life expectancy, literacy rate, mean MPCE, rural inflation, share of farm GSDP, social sector expenditure, and GDI. 
Table 1. Descriptive statistics and source of the variables

\begin{tabular}{|c|c|c|c|c|c|}
\hline Variables & Data Source & Mean & Std. Dev. & Min. & Max. \\
\hline \multicolumn{6}{|l|}{ Outcome variable } \\
\hline $\begin{array}{l}\text { Per capita gross private small } \\
\text { saving collections in post offices }\end{array}$ & National Savings Institute, Ministry of Finance, Gol & & & & \\
\hline and banks & & 3167.2 & 3536.1 & 407.1 & 16599.7 \\
\hline Predictor variable & Census of India 2001 \& Report of the Technical Group on & & & & \\
\hline Working-age ratio (\%) & Population Projections (2019) & 61.1 & 4.1 & 52.4 & 66.5 \\
\hline \multicolumn{6}{|l|}{ Covariates } \\
\hline $\begin{array}{l}\text { Social sector expenditure (as a \% of } \\
\text { GSDP) }\end{array}$ & $\begin{array}{l}\text { Goswami and Bezbaruah (2011) and RBI handbook of } \\
\text { state statistics }\end{array}$ & 10.5 & 4.8 & 4.3 & 21.8 \\
\hline Governance index & Mundle, Chowdhury, and Sikdar (2016) & 0.5 & 0.1 & 0.2 & 0.7 \\
\hline Wealth inequality & National Family Health Survey (NFHS) & 0.7 & 0.7 & 0.0 & 2.9 \\
\hline Share of farm GSDP & EPWRF & 20.3 & 7.1 & 7.0 & 33.0 \\
\hline Proportion of female headed & National Family Health Survey (NFHS) & & & & \\
\hline households & & 13.0 & 5.1 & 6.3 & 25.6 \\
\hline Rural inflation (CPI - RL) & Ministry of labour \& employment, Labour Bureau, Gol & 4.7 & 2.6 & -1.9 & 10.1 \\
\hline Urban inflation (CPI - IW) & Ministry of labour \& employment, Labour Bureau, Gol & 5.9 & 1.4 & 3.2 & 8.4 \\
\hline $\begin{array}{l}\text { Log mean monthly per capita } \\
\text { consumption expenditure }\end{array}$ & National Sample Survey Organisation & & & & \\
\hline (MPCE) & & 6.6 & 0.3 & 6.1 & 7.1 \\
\hline Literacy rate & Census of India & 71.0 & 9.6 & 47.0 & 94.0 \\
\hline Post office density & Report of Tenth Five Year Plan \& Lok Sabha Proceedings & 8.6 & 0.5 & 7.5 & 9.7 \\
\hline Bank density & RBI handbook of state statistics & 0.10 & 0.1 & 0.1 & 0.3 \\
\hline Gender development index & $\begin{array}{l}\text { Gendering Human Development Indices: Recasting the } \\
\text { Gender Development Index and Gender Empowerment } \\
\text { Measure for India (2009) }\end{array}$ & 0.8 & 0.1 & 0.5 & 0.9 \\
\hline Gender empowerment measure & Same as Gender development index & 0.5 & 0.1 & 0.4 & 0.7 \\
\hline Life expectancy & Sample Registration System & 67.3 & 3.9 & 59.2 & 75.1 \\
\hline Per capita income level & Central Statistical Organisation & 10.7 & 1.0 & 8.8 & 12.1 \\
\hline Growth in per capita income & Central Statistical Organisation & 8.1 & 4.6 & -3.4 & 18.7 \\
\hline
\end{tabular}

Note: Balanced panel data of 32 observations over 16 states in the 2001-2018 period. 


\section{Empirical Specification}

Panel data regression model is employed to control for variables that are not directly observable or measurable across states such as cultural factors or variables that change over time but not across entities. We have modelled F-test for the fixed effect (FE) model, Breusch-Pagan Lagrange Multiplier (LM) test for the random effect (RE) model and Hausman test to decide between FE or $\mathrm{RE}$ to be conducted. The main equation of interest of the panel data regression model used in this paper is given as:

Log per capita private saving $s_{i t}=\alpha+\beta_{0}$ Log working - age ratio it $_{+}$

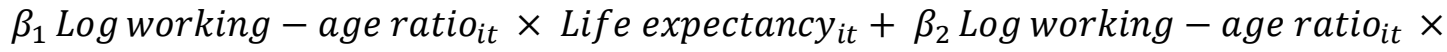
Literacy rate $_{i t}+\beta_{3}$ Log working - age ratio ${ }_{i t} \times$ Gender development index $_{i t}+$ $\beta_{4}$ Log working - age ratio it $\times$ Gender empowerment measure $_{i t}+$ $\beta_{5}$ Log working - age ratio $_{i t} \times \log$ per capita income it $+\beta_{6}$ Social sector expenditure $_{i t}+$ $\beta_{7}$ Governance index $+\beta_{8}$ Wealth inequality ${ }_{i t}+$

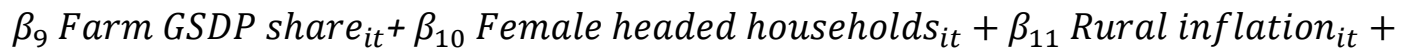
$\beta_{12}$ Urban inflation $_{i t}+\beta_{13}$ Log mean MPCE $E_{i t}+\beta_{14}$ Log literacy rate $_{i t}+\beta_{15}$ bank density $_{i t}+$ $\beta_{16}$ Log post office denisty ${ }_{i t}+\beta_{17}$ Growth in per capita inome ${ }_{i t}+u_{i}+v_{i t}$

Where, Log per capita private saving $s_{i t}$ represents the per capita private savings of state

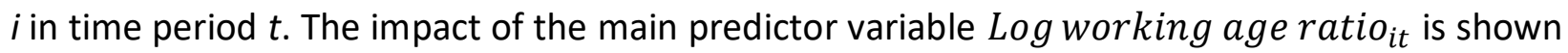
both individually and in interaction effects with the life expectancy, literacy rate, GDI, GEM, and per capita income. $\beta$ is the coefficient for independent variables; $u_{i}(i=1 . . . \mathrm{n})$ is a FE or RE specific to individual state or time period that is not included in the regression; $v_{i t}$ is the error term.

Further, an additional analysis is carried out to examine the influence of other potential determinants of private savings such as interest rates, external terms of trade, public savings, and wages. Since these indicators are not available at the provincial level, we have made a descriptive assessment of these indicators at the national level. Next, the reliability of the main results is checked in the robustness section by using, first, alternative econometric techniques of regression-based inequality decomposition model and instrumental variable model (two-stage least square) and, second, by employing an alternative sample which covers 28 states.

\section{Estimation Results}

\subsection{Main Results: Panel Data Regression Model to Quantify the Effect of Demographic on Private Savings}

\section{Baseline Results}

Table 2 reports the results of a fixed-effects model from equation (1). The baseline results in column (1) suggests the presence of a positive and statistically significant relationship between the log of the working age population and log of the per capita gross small saving collections in 
post offices and banks. More concretely, a one per cent increase in the working age population leads to an increase of $\mathbf{1 8 . 7}$ per cent in private savings. This model can explain 49 percent of the variations in private savings, suggesting that goodness of fit of the model where demographic changes explain a major proportion of variation in per capita private savings is upright.

\section{Inclusion of Control Variables}

In column (2), we can observe that with the inclusion of social sector expenditure and governance index, the coefficient of the working age population decreases in magnitude but remains positive and statistically significant at the conventional level. Social sector expenditure emerges as a significant determinant of private savings, which shows the importance of expenditure incurred by the state governments on social sectors such as education, healthcare and rural development, helping in reducing the out-of-pocket expenditure of households and thereby promoting private savings. In column (3) also the coefficient for the working age population is positive, statistically significant, and its magnitude decreases by only one percentage point when we control for farm GSDP share and wealth inequality. The farm GSDP share has a negative and statistically significant impact on private savings. This is in line with the findings of Krishnamurty and Saibaba (1981), M“uhleisen (1997) and Rakshit (1983), Column (4) controls for additional explanatory variables and there is a marginal change in the results. In column (5), we show that the presence of additional explanatory variables such as urban inflation, mean MPCE, and literacy rate do not significantly reduce the influence of working age population on the private savings. Among covariates, mean MPCE and literacy rate emerge as important factors driving private savings. Column (6) shows that a one percent rise in the working age population raises private savings by nine percentage points, holding bank density and post office density constant. These two measures of financial development (bank density and post office density) also emerged as significant determinants of private savings in the findings of Athukorala and Sen (2004), DayalGhulati and Thimann (1997), Horioka and Hagiwara (2010), Loayza et al. (2000a, 2000b), and Park and Shin (2009). The model's explanatory power improves significantly with adjusted R-squared reaching 71 percent.

Clearly, these results confirm the life cycle hypothesis that larger working age population leads to a rise in the savings. These findings are in line with the empirical literature based on cross-country panel data (Dayal-Ghulati \& Thimann, 1997; Fry \& Mason, 1982; Heller, 1989; Higgins \& Williamson, 1997; Kelley \& Schmidt, 1996; Leff, 1969; Loayza et al., 2001a; Mason, 1988; Modigliani, 1970; Yasin, 2008), time-series data for Pakistan (Ahmad, 2002; Akhtar, 1986; Ali, Ahmad, \& Butt, 1997; Burney \& Khan, 1992; Khan, Hasan, \& Malik, 1992), United States (Hurd, 1996; Pryor, 2003; Thornton, 2001), Japan (Horioka, 1997) and Nigeria (Uremadu, 2009) and particularly those studies with respect to India which covers it as one of the sample countries in the panel of cross-country data (Curtis, Lugauer, \& Mark, 2017; Higgins \& Williamson, 1997; Higgins, 1998; Horioka \& Hagiwara, 2010; Park \& Shin, 2009). 


\section{Interaction Analysis}

Columns $(7,8,9$ and 10$)$ demonstrate the possible interaction effects of the demographic change with key socio-economic covariates to ascertain whether the positive effect of working age population on private savings is conditioned by the socio-economic environment of the country. In column (7), we observe that the estimated private savings effect of the interaction of working age population with the life expectancy and literacy rate is positive and statistically significant, implying that healthy and educated working age population is essential to raise private savings. Previous empirical studies by Krueger (2004) and Park and Shin (2009) also found that an increase in life expectancy increases the post-retirement period of an individual and hence the income has to be stretched for a longer time horizon. This leads to a rise in savings in all periods of an individual's life.

In columns (8) and (9), working age population is interacted with the effective instruments of gender equity that is GDI and GEM. The interaction terms reveal positive and statistically significant relationship, suggesting that the level of gender equity significantly positively adjusts the positive impact of the working age population on private savings. Thus, India need to make higher level of investment in women's health, education, and economic opportunities, then only it can realise the fruits of 'gender dividend' which is causally related to higher saving rates and economic growth rates. This is in line with the theoretical arguments put forward by Bloom (2011) and Desai (2010).

In the final column, column (10), working age population interacts with the per capita income level. The estimated private savings effect is positive and statistically significant. It indicates that the higher the level of per capita income is, the stronger the positive impact of working age population on private saving will be. This asserts that policies that support development help in stimulating savings by the working-age group, a result consistent with the findings of Athukorala and Sen (2004), Dayal-Ghulati and Thimann (1997), Horioka and Hagiwara (2010), Loayza et al. (2000a, 2000b), Modigliani (1970). The adjusted R-squared of the model reaches 78 percent in the final column, suggesting a good fit of the model.

In summary, the results of the interaction analysis suggest that opening of the window of economic opportunity for India could result in higher private savings if favourable socioeconomic policy environment is in place, such as healthy and educated working-age population, higher gender equity, and a higher level of per capita income. 
Table 2. Impact of working-age population share on per capita private savings

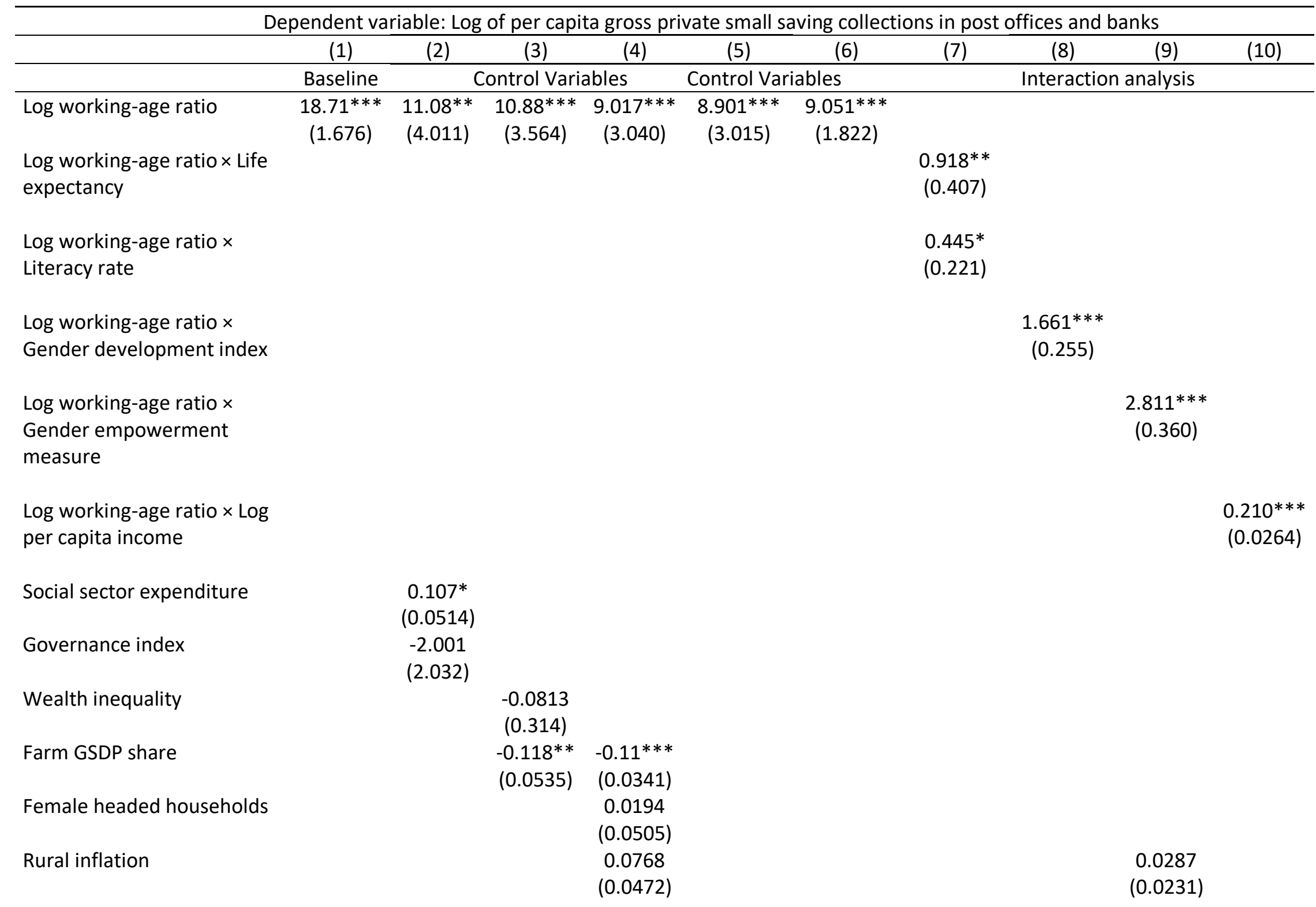




\begin{tabular}{|c|c|c|c|c|c|c|c|c|c|c|}
\hline Urban inflation & & & & & $\begin{array}{l}-0.0449 \\
(0.0636)\end{array}$ & & & $\begin{array}{l}-0.0978^{*} \\
(0.0518)\end{array}$ & & \\
\hline Log mean MPCE & & & & & $\begin{array}{c}3.643 * * * \\
(1.192)\end{array}$ & & & & & \\
\hline Log literacy rate & & & & & $\begin{array}{c}3.642 * * * \\
(0.904)\end{array}$ & & & & & \\
\hline Bank density & & & & & & $\begin{array}{c}14.69 * * * \\
(3.221)\end{array}$ & $\begin{array}{c}13.00 * * * \\
(3.317)\end{array}$ & $\begin{array}{c}19.45^{* * *} \\
(1.433)\end{array}$ & $\begin{array}{c}9.042 * * * \\
(2.714)\end{array}$ & \\
\hline Post office density & & & & & & $\begin{array}{c}0.464^{* *} \\
(0.183)\end{array}$ & $\begin{array}{l}0.345^{*} \\
(0.191)\end{array}$ & $\begin{array}{c}0.342^{* *} \\
(0.157)\end{array}$ & $\begin{array}{c}0.330^{* *} \\
(0.123)\end{array}$ & \\
\hline Growth in per capita income & & & & & & & & & & $\begin{array}{c}0.0178 \\
(0.0209)\end{array}$ \\
\hline Constant & $\begin{array}{c}-69.3^{* * *} \\
(6.888)\end{array}$ & $\begin{array}{c}-38.16^{* *} \\
(16.36)\end{array}$ & $\begin{array}{c}-34.73 * * \\
(15.58)\end{array}$ & $\begin{array}{c}-27.91^{* *} \\
(13.04)\end{array}$ & $\begin{array}{c}-68.39 * * * \\
(5.913)\end{array}$ & $\begin{array}{c}-35.15^{* * *} \\
(7.044)\end{array}$ & $\begin{array}{c}-20.42^{* * *} \\
(4.581)\end{array}$ & $\begin{array}{c}-2.218^{* *} \\
(0.816)\end{array}$ & $\begin{array}{c}-2.353^{*} \\
(1.316)\end{array}$ & $\begin{array}{c}-1.872 * \\
(1.000)\end{array}$ \\
\hline Observations & 32 & 32 & 32 & 32 & 32 & 32 & 32 & 32 & 32 & 32 \\
\hline Groups & 16 & 16 & 16 & 16 & 16 & 16 & 16 & 16 & 16 & 16 \\
\hline R-squared & 0.49 & 0.59 & 0.53 & 0.54 & 0.50 & 0.73 & 0.75 & 0.69 & 0.70 & 0.80 \\
\hline Adjusted R-squared & 0.49 & 0.55 & 0.48 & 0.48 & 0.43 & 0.71 & 0.71 & 0.65 & 0.67 & 0.78 \\
\hline State effects & YES & YES & YES & YES & YES & YES & YES & YES & YES & YES \\
\hline
\end{tabular}

Note: Standard errors are robust clustered at state level. ${ }^{* *} p<0.01,{ }^{* *} p<0.05,{ }^{*} p<0.1$. All models are based on the Fixed Effects estimation.

The VIF (variance inflation factor) values in all the models is less than 3 , suggesting no problem of multicollinearity. 


\section{Additional Analysis}

Although the study controls for a range of key socio-economic variables to estimate a net demographic effect on private savings, an extension of the study is possible by checking for the influence of other potential determinants of private savings, such as interest rates, external terms of trade, public savings, and wages. Since these indicators are not available at the provincial level, we could not include them in our main analyses. In this section, we have made a descriptive assessment of these indicators at the national level.

The effect of interest rates on private savings is theoretically ambiguous. A higher interest rate can encourage private savings as the substitution effect makes current consumption relatively expensive. However, the income effect tends to reduce private savings with the rise in interest rates by raising current income of an individual who is a net lender. Previous empirical research also presented mixed evidence. Athukorala and Sen (2004) found a positive effect of real rate of return on bank deposits on private saving rate in India, using time series data for the period 1954-1998. Globally, Ogaki, Ostri, and Reinhart (1996), and Masson, Bayoumi, and Samiei (1998) have also found positive effects on private savings while Bosworth (1993) found negative effects in a panel estimation.

Another potential determinant of private savings is external terms of trade. The relationship between the two is based on the Harberger-Laursen-Metzler hypothesis, which states that an improvement in the terms of trade raises price of domestically produced goods relative to that of foreign goods and increases real income and savings. This hypothesis assumes that consumers have short-term expectations. On the other hand, if consumers are assumed to be forward looking, then its effects depend on whether there is a transitory or permanent change in the terms of trade. A transitory change in the terms of trade and private savings has a positive correlation, in line with Obstfeld (1982)'s hypothesis which says that a permanent deterioration in the terms of trade may increase savings in the current period by domestic residents who want to maintain the real standard of living in the future (Athukorala \& Sen, 2004; Masson, Bayoumi, \& Samiei, 1998).

The impact of public savings on private savings is also noteworthy. The extreme case presented by Ricardian equivalence implies that public and private savings are perfect substitutes, provided there are perfect capital markets and no uncertainty in savings behavior. However, in real world, these assumptions may not hold (Athukorala \& Sen, 2004). Also, different government policies can have varied impact on private savings. For instance, a higher government expenditure may reduce the resources available to private sector and hence reduce their savings. Whereas, if a government undertakes a productive public investment, which may not require further taxes in the future, may not significantly offset private savings. Previous empirical results also reject the Ricardian equivalence hypothesis (see Masson, Bayoumi, \& Samiei, 1998 for a detailed review of the empirical literature). Lastly, the effect of wages on 
private savings is analyzed in the Indian context considering that it may have a direct impact on private savings.

Given the above theoretical background, we conduct graphical analysis to check whether there is any relationship between private savings and interest rates, external terms of trade, public savings, and wages by exploiting time series data for India for the period 2000-2018 at an approximate interval of five years. The data for per capita private savings is obtained from National Savings Institute, Ministry of Finance, Government of India. The working age ratio data is collected from World Population Prospects (19th Revision), United Nations 2019. Weighted average call money rate provided by the $\mathrm{RBI}$ is used to measure interest rates. External terms of trade data is taken from RBI and trading economics.com. The data for public savings is collected from Central Statistics Office (CSO) and the wages data from annual reports of labour bureau. The graphical analysis (Figure 4) clearly highlights that wages along with demographic factor is in tandem with private savings whereas other factors such as terms of trade, public savings, and interest rate do not exhibit any systematic relationship with private savings in the Indian context during the period 2000-2018. Thus, wages seem to play an important role in determining private savings.

Figure 4. Trends in Other Potential Determinants of Private Savings (2000-2020)

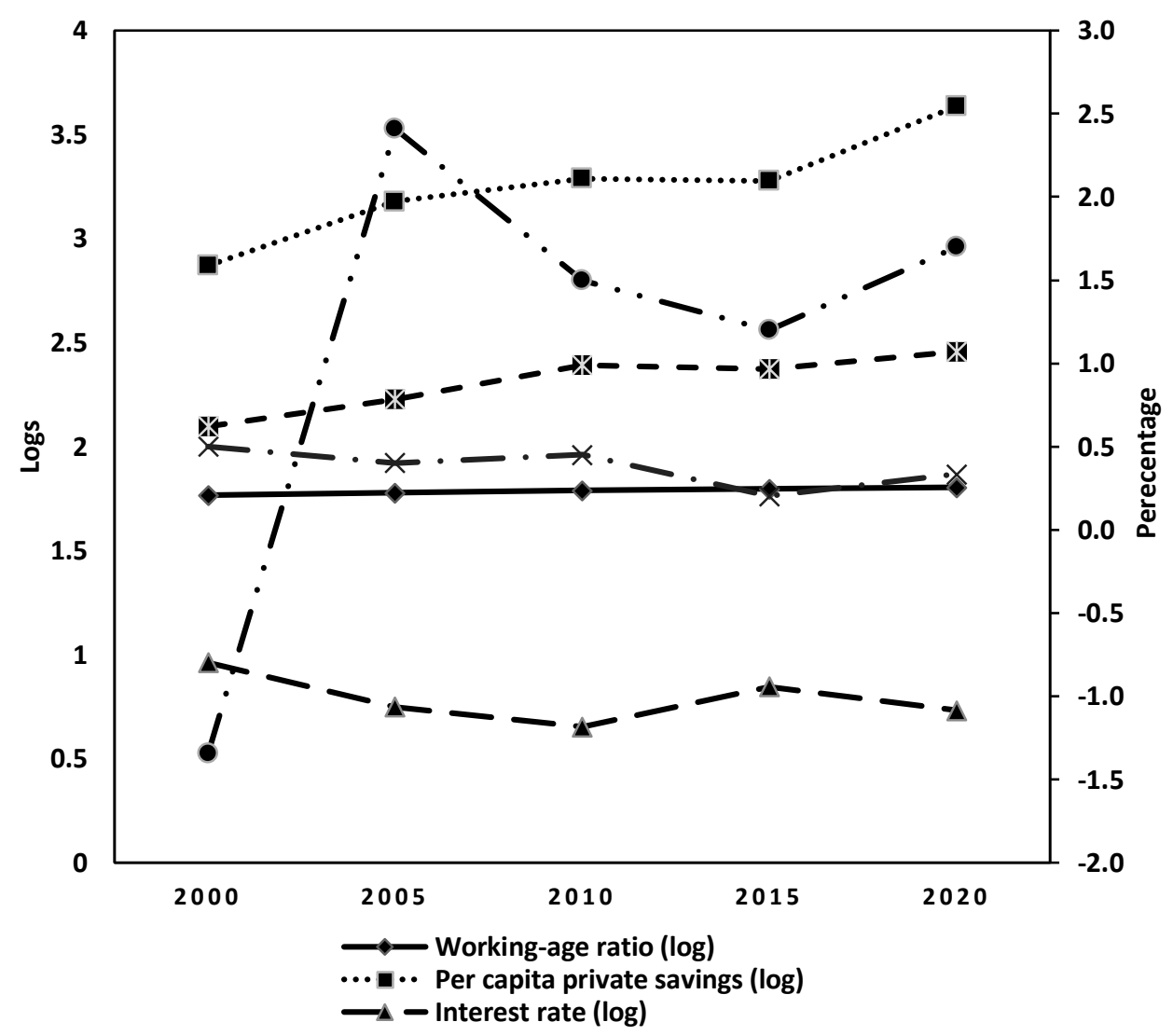

Source: Authors' calculations from various sources 


\subsection{Robustness Checks}

In this section, we examine the robustness of our findings for different econometric techniques and alternative sample. Below we discuss in more detail some of the robustness checks performed.

(i) Relative contribution of the working age population to per capita private savings inequality: regression-based inequality decomposition model

In this method, first, a saving-generating function is set as

$\ln \left(s_{i}\right)=\alpha+\sum_{i=1}^{k} \beta_{i} x_{i}+\varepsilon$

where $s_{i}$ is per capita private savings for $i=1, \ldots ., k, x_{i}$ is a vector of explanatory variable; $\beta_{i}$ are the corresponding regression coefficients estimated by OLS regression; and $\varepsilon$ is the residual term, assumed to be unrelated to other variables.

$\ln \left(s_{i}\right)=\alpha+\sum_{i=1}^{k} Z_{i}+\varepsilon$

where each $Z_{i}$ for $i=1, \ldots ., k$. is a 'composite' variable, equal to the product of an estimated regression coefficient and an explanatory variable. To calculate inequality decomposition, the value of $\alpha$ is not relevant as it is constant for every observation. Thus, one may consider the following equation

$\ln \left(\widehat{s_{l}}\right)=\alpha+\sum_{i=1}^{k} Z_{i}$

where dependent variable is $s_{i}$ hat or predicted savings variable. Note, there is no residual term and we can neglect the constant term $\alpha$.

Following Fields and Yoo (2000), Fields (2003), and Shorrocks (1982), the contribution of each composite variable to total per capita private savings inequality can then be assessed as follows: $\sigma^{2}(\mathrm{~s})=\sum_{i=1}^{k} \beta_{i} \operatorname{cov}\left(\mathrm{s}, x_{i}\right)+\sigma^{2}(\varepsilon)$

where, $\sigma^{2}(\mathrm{~s})$ is the variance of $s, \operatorname{cov}\left(\mathrm{s}, x_{i}\right)$ represents the covariance of $s$ with each variable $\left(x_{i}\right)$ and this term can be considered as the relative contribution of factor components to total per capita private savings inequality, which sums to 100 percent.

The Appendix table A2 presents four different models of pooled OLS regression from equation (4) based on the correlation among explanatory variables. Table 3 from equation (5) reveals that around one-fourth of per capita private savings inequality is contributed by the working age population across the states, after controlling other core policy variables in different models. This reinforces the significance of working age population in determining per capita private savings. Bank density is another important variable which explains around 40 percent of the private savings inequality across the states. GEM contributes to around 22 percent of the regional savings inequality and is followed by social sector expenditure (explaining around 11 to 15 percent), and post office density (explaining around nine percent). 
Table 3. Estimates of regression-based inequality decomposition model-Contribution of variation in working-age population share to inequality in per capita private savings (in percentage)

Dependent variable: Log of per capita gross private small saving collections in post offices and banks

\begin{tabular}{|c|c|c|c|c|}
\hline & (1) & (2) & (3) & (4) \\
\hline Log working-age ratio & $27.84^{*}$ & $23.12^{*}$ & $24.38^{*}$ & $26.35 * *$ \\
\hline Log life expectancy & & 16.59 & & \\
\hline Log literacy rate & 14.57 & & & \\
\hline Gender development index & & & & 0.56 \\
\hline Gender empowerment measure & & & $22.33^{* *}$ & \\
\hline Social sector expenditure & $14.19 * *$ & $15.47 * *$ & $11.04^{*}$ & 7.08 \\
\hline Governance index & & & & -3.19 \\
\hline Wealth inequality & & & & -0.46 \\
\hline Farm GSDP share & & & 2.01 & \\
\hline Female headed households & 0.12 & & & \\
\hline Rural inflation & 4.68 & 3.40 & 6.33 & \\
\hline Urban inflation & 0.28 & & & \\
\hline Log mean MPCE & & 8.99 & & \\
\hline Bank density & & & & $40.31 * * *$ \\
\hline Post office density & $9.38 * *$ & $7.45^{* *}$ & $7.18^{* *}$ & $8.89 * * *$ \\
\hline
\end{tabular}

Note: Standard errors in parentheses. ${ }^{* * *} \mathrm{p}<0.01,{ }^{* *} \mathrm{p}<0.05,{ }^{*} \mathrm{p}<0.1$. The Pooled OLS Regression of Decomposition model is given in Appendix Table A2.

(ii) Checking endogeneity of the working age population: Instrumental variable model In this method, we address the possible endogeneity issue in working age population as its influence on private savings may work through various channels such as education, health, level of development, and gender equity. Bloom et al. (2003) and Bloom (2011) have highlighted the significance of these channels for the realisation of demographic dividend. On this line, we take literacy rate, life expectancy, per capita income, growth in per capita income, and GEM as instruments. The statistical expression for the model is as follows: 
Log per capita private savings $s_{i t}=\alpha+\beta_{0}$ (Log working - age ratio $_{i t}=$ $\log {\text { literacy } \text { rate }_{i t}, \log \text { life expectancy }_{i t}, \log \text { per capita income }}_{i t}$, growth in per capita income $_{i t}$, , gender empowerment measure $\left.e_{i t}\right)+\beta_{i}$ Control variables $i t+u_{i t}$.

where Log per capita private savings $s_{i t}$ is the dependent variable; Log working age ratio $_{i t}$ is the instrumented variable; other explanatory variables have the usual interpretation.

The (Two stage least square) 2SLS estimates from equation (6) presented in Table 4 suggest magnified statistical significant bearing of the working age population on per capita private savings. The results are quantitatively similar in column (2) when compared to the final estimates of panel data regression model. To be precise, a one per cent rise in the share of working age population increases per capita private savings by around nine per cent, when instrumented by literacy rate, life expectancy, per capita income, growth in per capita income, and GEM, while controlling for other variables. The test of endogeneity confirms that working age population is an endogenous variable as the null hypothesis of exogeneity of the working age population is rejected at a conventional level of significance. The instruments used are valid as per the test of over-identifying restrictions, and the value of F-statistic shows that the instruments are not weakly correlated with the endogenous regressors.

Table 4. Estimates from instrumental variables model (2SLS) - checking endogeneity of workingage population share

\begin{tabular}{llc}
\hline \multicolumn{3}{l}{ Dependent variable: Log of per capita gross private small saving collections in post offices and banks } \\
\hline & $(1)$ & $(2)$ \\
\hline Log working-age ratio & $17.28^{* * *}$ & $9.196^{* * *}$ \\
& $(3.770)$ & $(2.460)$ \\
Social sector expenditure & & 0.0287 \\
& & $(0.0297)$ \\
Governance index & $-3.521^{* *}$ & \\
& $(1.665)$ & 0.254 \\
Wealth inequality & 0.152 & $(0.210)$ \\
& $(0.299)$ & \\
Farm GSDP share & $0.0347^{*}$ & \\
& $(0.0183)$ & \\
Female headed households & 0.0250 & -0.0334 \\
Rural inflation & $(0.0307)$ & $(0.0506)$
\end{tabular}


Urban inflation

(0.0812)

Log mean MPCE

Bank density

Post office density

Observations

Groups

R-squared

First stage F statistic
1.400

$9.642 * * *$

$0.797^{* * *}$

(0.283)

$0.687 * * *$

32

32

16

16

0.64
0.76

10.11

Over-identifying Restrictions (Ho: zero correlation between instruments and the error term)

Sargan chi2

$4.6638(p=0.3236)$

$3.0584(p=0.5481)$

Exogeneity of instrumented explanatory variable (Ho: Variable is exogenous)

Robust score $\quad 7.6555(p=0.0057)$

Robust regression $\quad 8.0201(p=0.0094)$

$6.4361(p=0.0112)$

$10.8526(p=0.0032)$

Note: Robust Standard errors in parentheses. ${ }^{* *} \mathrm{p}<0.01,{ }^{* *} \mathrm{p}<0.05,{ }^{*} \mathrm{p}<0.1$. Gender development index is not included in the regression due to high pairwise correlation with the instruments used.

(iii) Checking endogeneity of the growth in per capita income: Instrumental variable model

The results reported in the panel data regression model (main results from Table 2) are valid only if growth drives private savings during the period considered. There might be an issue of endogeneity of the growth in per capita income since savings leads to a higher capital accumulation and hence higher economic growth (Mankiw, Romer, \& Weil, 1992). Loayza et al. (2000a, 2000b) found that growth in per capita income may be jointly endogenous with the saving rates and controlled for this endogeneity using "internal instruments," that is by taking its lagged values. We check for the possibility of reverse causality in saving regression by using the instrumental variable model and taking lagged growth in per capita income as an instrument. The statistical expression for the model is as follows:

Log per capita private saving $s_{i t}=\alpha+\beta_{0}$ (growth in per capita income $e_{i t}=$ ${\left.\text { growth in per capita } \text { income }_{i t-1}\right)+\beta_{i} \text { Control variables }}_{i t}+u_{i t}$

where growth in per capita income $_{i t-1}$ represents the lagged growth in per capita income. Table 5 reports the instrumental variable estimated results for equation (7). It shows 
that the growth in per capita income is an exogenous variable as, in the endogeneity test, the null hypothesis of exogeneity of the instrumented explanatory variable is not rejected at a conventional level of significance. The coefficient of the growth in per capita income is also similar in magnitude and statistically insignificant as found in Table 2. These results rule out the possibility of reverse causality in the main results. We can conclude that growth drives private saving in our model, which is in line with the predictions of Modigliani (1970). Attanasio, Picci, and Scorcu (2000), and Deaton and Paxon (2000), examining the link between savings and economic growth, also found that growth Granger-causes savings and a rise in economic growth will follow a rise in savings.

Table 5. Estimates of instrumental variables model (2SLS)-checking endogeneity of growth in per capita income

Dependent variable: Log of per capita gross private small saving collections in post offices and banks

Log working-age ratio $\times$ Log per capita income

$0.378^{* * *}$

(0.126)

Governance index

(2.334)

Farm GSDP share

$-0.00510$

(0.0501)

Female headed households

$0.0664 * *$

(0.0291)

Rural inflation

$-0.201 * * *$

(0.0672)

Urban inflation

0.0923

(0.177)

Log literacy rate

1.162

(2.529)

Growth in per capita income

0.0580

(0.153)

Constant

$-13.94 * *$

(7.050)

Observations 16

$\begin{array}{ll}\text { R-squared } & 0.58\end{array}$

Exogeneity of instrumented explanatory variable (Ho: Variable is exogenous)

Robust score chi2(1) $\quad=1.92534(p=0.1653)$

Robust regression $\mathrm{F}(1,6) \quad=1.75867(\mathrm{p}=0.2330)$

Note: Robust Standard errors in parentheses. ${ }^{* * *} p<0.01,{ }^{* *} p<0.05,{ }^{*} p<0.1$. 


\section{(iv) Using an alternative sample}

In Table 6, we present estimates for an alternative sample of states covering 28 states of India 4 to compare these estimates with the baseline result for the 16 major states of India. To choose between RE and FE, necessary tests, $\mathrm{F}$ test, Breusch-Pagan Lagrange Multiplier (LM) test and Hausman test are conducted to determine the model. The model is based on FE estimation. Panel data regression is run by using population-adjusted weighted regression. The results reveal that the estimate is broadly analogous to the one found for the major states, thus strengthening the robustness of the baseline result.

Table 6. Impact of working-age population share on per capita private savings in 28 states of India

Dependent variable: Log of per capita gross private small saving collections in post offices and banks

(1)

Log working-age ratio

$18.11^{* * *}$

Constant

Observations

Groups

R-squared

Adjusted R-squared

0.49

State effects

YES Note: Robust standard errors in parentheses. ${ }^{* * *} p<0.01,{ }^{* *} p<0.05,{ }^{*} p<0.1$.

In summary, the evidence we present in this section implies that the working age population has a strong causal effect on the per capita gross small savings collection in post offices and banks in India.

\section{Conclusion}

The role of the bulging working age population in private savings specific to the Indian context remains unclear in previous empirical evidence as the only available study investigated this relationship before the onset of the demographic window of economic opportunities for the country is by Athukorala and Sen (2004). Moreover, this study assessed only national-level time

\footnotetext{
${ }^{4}$ The states included are Andhra Pradesh, Arunachal Pradesh, Assam, Bihar, Delhi, Goa, Gujarat, Haryana, Himachal Pradesh, Jammu and Kashmir, Karnataka, Kerala, Madhya Pradesh, Maharashtra, Manipur, Meghalaya, Nagaland, Odisha, Punjab, Rajasthan, Sikkim, Tamil Nadu, Tripura, Uttar Pradesh, West Bengal, Jharkhand, Chhattisgarh, and Uttaranchal.
} 
series data. To the best of our knowledge, our paper is the first one to investigate the impact of demographic changes on per capita gross small savings in post offices and banks net of socioeconomic characteristics using state-level panel data compiled from multiple data sources for the period 2001-2018. Our comprehensive econometric assessment with multiple robustness checks present three key findings: First, there exists a positive relation between the working age population and private small savings, consistent with the economic life cycle hypothesis. To be precise, a one percent rise in the working age population raises per capita private savings by nine percentage points, holding other factors constant. Second, the demographic factor explains around one-fourth of the per capita private savings inequality across the states and over time. Third, the demographic window of economic opportunity for India could yield maximum benefits in terms of private savings when accompanied by a favourable socio-economic policy environment related to education, health, gender equity, and economic growth.

\section{Data availability}

The data underlying this article will be shared on reasonable request to the corresponding author.

\section{Declaration of Conflict of Interest: None}

This paper did not receive any specific grant from funding agencies in the public, commercial, or not-for-profit sectors.

\section{References}

Adams, N. A. (1971). Dependency rates and saving rates: Comment. American Economic Review, 61(3), 472-75.

Ahmad, M. H. (2002). The Impact of the Age Structure of Population on the Household Saving Rate in Pakistan: A Cointegration Approach. Savings and Development, 26(3), 289-300.

Ali, N., Ahmad, E., \& Butt, A. R. (1997). Dependency Burdens and Savings Rates in Pakistan A New Strategic Study. Pakistan Economic and Social Review, 35(2), 95-130.

Akhtar, S. (1986). Saving-income relation in urban Pakistan: evidence from HIES 1979, Pakistan. Journal of Applied Economics, 5(1).

Attanasio, O., Picci, L., \& Scorcu, A. (2000). Saving, Growth, and Investment. Review of Economics and Statistics, 82(2), 182-211.

Athukorala, P. C., \& Sen, K. (2004). The determinants of private saving in India. World Development, 32(3), 491-503.

Birdsall, N., Kelley, A. C., \& Sinding, S. (2003). Population Matters: Demographic Change, Economic Growth, and Poverty in the Developing World. Oxford Scholarship Online. ISBN-13: 9780199244072. DOI:10.1093/0199244073.001.0001 
Bloom, D. E., \& Williamson, J. G. (1998). Demographic Transitions and Economic Miracles in Emerging Asia. World Bank Economic Review, 12(3), 419-56.

Bloom, D. E., Canning, D., \& Sevilla, J. (2003). The demographic dividend: A new perspective on the economic consequences of population change. Santa Monica, CA: Rand.

Bloom, D. E. (2011). Population Dynamics in India and Implications for Economic Growth. PGDA Working Paper No.65. Retrieved from http://www.hsph.harvard.edu/program-onthe-global-demography-of aging/WorkingPapers/2011/PGDA_WP_65.pdf.

Bosworth, B. P. (1993). Saving and Investment in a Global Economy. Washington, DC: Brookings Institution.

Burney, N. A., \& Khan, A. H. (1992). Socio-economic characteristics and house-hold saving: An analysis of household saving behavior in Pakistan. The Pakistan Development Review, 31(1), 31-48.

Coale, A. J., \& Hoover, E. (1958). Population growth and Economic Development in Low Income Countries-A Case Study of India's Prospects. Princeton, NJ: Princeton University Press.

Census of India. (2001). Office of Registrar General, Ministry of Home Affairs, Government of India.

Curtis, C. C., Lugauer, S., \& Mark, N. C. (2017). Demographics and aggregate household saving in Japan, China, and India. Journal of Macroeconomics, 51, 175-191.

Dayal-Ghulati, A., \& Thimann, C. (1997). Saving in Southeast Asia and Latin America Compared: Searching for Policy Lessons. IMF Working Paper WP/97/110.

Retrieved from: https://www.imf.org/external/pubs/ft/wp/wp97110.pdf

Deaton, A., \& Paxson, C. (2000). Saving and Growth: Another Look at the Cohort Evidence. Review of Economics and Statistics, 82(2), 212-25.

Desai, S. (2010). The Other Half of the Demographic Dividend. Economic \& Political Weekly, 14(40), 12-14.

Dreze, J., \& Srinivasan, P. V. (1997). Widowhood and Poverty in Rural India: Some Inferences from Household Survey Data. Journal of Development Economics, 54(2), 217-234.

Fields, G., \& Yoo, G. (2000). Falling labour income inequality in Korea's economic growth: patterns and underlying causes. Review of Income Wealth, 46(2), 139-159.

Fields, G. (2003). Accounting for Income Inequality and Its Change: A New Method, with Application to the Distribution of Earnings in the United States. Research in Labor Economics.

Fry, M., \& Mason, A. (1982). The variable rate-of-growth effect in the lifecycle saving model: Children, capital inflows, interest and growth in a new specification of the life-cycle model applied to seven Asian developing countries, Economic Inquiry, 20, 426-442.

Gangopadhyay, S., \& Wadhwa, W. (2003). Are Indian Female-headed Households more Vulnerable to Poverty. India Development Foundation. Retrieved from: 
https://www.researchgate.net/publication/238622873_Are_Indian_femaleheaded_households_more_vulnerable_to_poverty

Gersovitz, M. (1988). Saving and Development. In H. Chenery \& T.N. Srinivasan (Eds.), Handbook of Development Economics ( $1^{\text {st }}$ ed., pp. 381-424). Amsterdam: North Holland.

Goldberger, A. (1973). Dependency rates and savings rates: Comment, American Economic Review, 63, 232-233.

Goswami, B., \& Bezbaruah, M. P. (2011). Social Sector Expenditures and Their Impact on Human Development: The Indian Experience. Indian Journal of Human Development, 5(2).

Gupta, K. L. (1971). Dependency Rates and Savings Rates: Comment. The American Economic Review, 61(3), 469-471.

Heller, P. S. (1989). Aging, Savings, and Pensions in the Group of Seven Countries: 1980-2025. Journal of Public Policy, 9(2), 127-155.

Higgins, M., \& Williamson, J. G. (1997). Age structure dynamics in Asia and dependence of foreign capital. Population and Development Review, 23(2), 261-293.

Higgins, M. (1998). Demography, National Savings, and International Capital Flows. International Economic Review, 39(2), 343-369.

Horioka, C. Y. (1997). A cointegration analysis of the impact of the age structure of the population on the household saving rate in Japan. Review of Economics and Statistics, 79(3), 511-516.

Horioka, C. Y., \& Hagiwara, A. T. (2010). Determinants and Long-term Projections of Saving Rates in Developing Asia. Asian Development Bank Economics Working Paper Series No.228. Retrieved from: https://www.adb.org/sites/default/files/publication/28429/economics-wp228.pdf.

Hurd, M. D. (1996). The Effects of Demographic Trends on Consumption, Saving, and Government Expenditures in the United States. In M. D. Hurd \& N. Yashiro (Eds.), The Economic Effects of Aging in the United States and Japan (pp. 39-57): University of Chicago Press.

Hu Q., Lei, X., \& Zhao, B. (2020). Demographic changes and economic growth: impact and mechanisms. China Economic Journal, DOI: 10.1080/17538963.2020.1865647.

Jha, S., Prasad, E., \& Terada-Hagiwara, A. (2009). Saving in Asia: Issues for Rebalancing Growth. Asian Development Bank Economics Working Paper Series No. 162.

Kelley, A. C., \& Schmidt, R. M. (1996). Saving, dependency and development. Journal of Population Economics, 9, 365-386.

Khan, A. H., \& Malik, A. (1992). Dependency ratio, foreign capital inflows and rate of savings in Pakistan. The Pakistan Development Review, 3(4), 843-56.

Kim, Y. C., \& Zang, H. (1997). Dependency Burden and Savings: A New Approach to the Old Query. The Journal of Developing Areas, 32(1), 29-36.

Krishnamurty, K., \& Saibaba, P. (1981). Determinants of Savings Rates in India. Indian Economic Review, 16(4), 225-49. 
Leff, N. (1969). Dependency Rates and Savings Rates. The American Economic Review, 59(5), 886-896.

Lee, R., Mason, A. \& Miller, T. (2000). Life Cycle Saving and the Demographic Transition in East Asia. Population and Development Review, 26(Supplement).

Loayza, N., Schmidt-Hebbel, K., \& Serven, L. (2000a). What Drives Private Saving Across the World? Review of Economics and Statistics, 82(2), 165-181.

Loayza, N., Schmidt-Hebbel, K., \& Serven, L. (2000b). Saving in Developing Countries: An Overview. The World Bank Economic Review, 14(3), 393-414.

Mankiw, N. G., Romer, D., \& Weil, D. N. (1992). A Contribution to the Empiricism of Economic Growth. Quarterly Journal of Economics, 107(2), 407-37.

Mason, A. (1988). Saving, Economic Growth, and Demographic Change. Population and Development Review, (1), 113-144.

Mason, A. (2001). Population Change and Economic Development in East Asia: Challenges Met, Opportunities Seized. Stanford: Stanford University Press.

Mason, A., \& Kinugasa, T. (2008). East Asian Economic Development: Two Demographic Dividends. Journal of Asian Economics, 19(5-6), 389-399.

Mason, A., Lee, R., \& Jiang, J. X. (2016). Demographic Dividends, Human Capital, and Saving. Journal of the Economics of Ageing, 7, 106-122.

Masson, P. R., Bayoumi, T., \& Samiei, H. (1998). International Evidence on the Determinants of Private Saving. The World Bank Economic Review, 12(3), 483-501.

M“uhleisen, M. (1997). Improving India's Saving Performance. Working Paper No. 97/4, International Monetary Fund, Washington, DC, USA.

Modigliani, F., \& Brumburg, R. (1954). Utility Analysis and the Consumption Function. In Post Keynesian Economics, edited by K.K. Kurihara. New Brunswick. NJ: Rutgers University Press.

Modigliani, F. (1970). The life cycle hypothesis of saving and intercountry difference in the saving ratio. In W. Eltis, M. FG. Scott \& J. N. Wolfe (Eds.), Induction, growth and trade: Essay in honour of Sir Harrod (pp. 197-225). London: Clarendon/Oxford University Press.

Meenakshi, J. V., \& Ray, R. (2002). Impact of household size and family composition on poverty in rural India. Journal of Policy Modeling.

Ministry of Skill Development \& Entrepreneurship, Government of India. (2015). Report on National Policy for Skill Development and Entrepreneurship. Retrieved from:

Http://Pibphoto.Nic.In/Documents/Rlink/2015/Jul/P201571503.Pdf

Ministry of Women \& Child Development, Government of India. (2009). Gendering Human Development Indices: Recasting the Gender Development Index and Gender Empowerment Measure for India. Retrieved from: https://www.undp.org/content/dam/india/docs/gendering_human_development_indic es summary report.pdf. 
Ministry of Finance, Government of India. (2011). Report of the Committee on Comprehensive Review of National Small Savings Fund. Retrieved from: https://www.finmin.nic.in/sites/default/files/Report_Committee_Comprehensive_R eview_NSSF.pdf

Ministry of Finance, Government of India. (2017-18). Annual report on analysis of trends of small savings collections. National Savings Institute. Retrieved from:

http://www.nsiindia.gov.in/writereaddata/FileUploads/UpdatedAnnualReport201718.pdf

Mundle, S., Chowdhury, S., \& Sikdar, S. (2016). Governance Performance of Indian States 200102 and 2011-12. National Institute of Public Finance and Policy Working Paper No. 164. Retrieved from: http://nipfp.org.in/publications/working-papers/

National Commission on Population, \& Ministry of Health \& Family Welfare. (2019). Report of the Technical Group on Population Projections for India and States 2011 -2036. Retrieved from: https://nhm.gov.in/New_Updates_2018/Report_Population_Projection_2019.pdf

Nelson, J. A. (1988). Household Economies of Scale in Consumption: Theory and Evidence. Econometrica, 56, 1310-1314.

Obstfeld, M. (1982). Aggregate Spending and the Terms of Trade: Is There a Laursen-Metzler Effect? The Quarterly Journal of Economics, 97(1), 251-70.

Ogaki, M., Ostry, J. D., \& Reinhart, C. M. (1996). Saving Behavior in Low and Middle-Income Developing Countries: A Comparison. IMF Staff Papers, 43(1), 38-71.

Park. D., \& Shin, K. (2009). Saving, Investment, and Current Account Surplus in Developing Asia. Asian Development Bank Economics Working Paper Series No. 158. Retrieved from: https://www.adb.org/sites/default/files/publication/28249/economics-wp158.pdf

Pryor, F. L. (2003). Demographic Effects on Personal Saving in the Future. Southern Economic Journal, 69(3), 541-559.

Rakshit, M. (1983). On assessment and interpretation of saving-investment estimates in India. Economic and Political Weekly, 19(2), 753-776.

Rajaram, R. (2009). Female-Headed Households and Poverty: Evidence from the National Family Health Survey. Retrieved from:

http://citeseerx.ist.psu.edu/viewdoc/download?doi=10.1.1.618.1880\&rep=rep1\&type=

pdf

Ram, R. (1982). Dependency rates and aggregate savings: A new international cross-section study. $\quad$ The American Economic Review, 72, 537-44.

. (1984). Dependency rates and savings: Reply. The American Economic Review, 74(1), 234-37.

Reserve Bank of India. (2018). Handbook of Statistics on Indian States. Retrieved from: https://rbidocs.rbi.org.in/rdocs/Publications/PDFs/OHANDBOOK201819 FDF254115C6 094E3CAB32A1DCDA9ADA88.PDF 
Rossi, N. (1989). Dependency rates and private savings behaviour in developing countries. IMF Staff Papers, 36(1), 166-81.

Samantaraya, A., \& Patra, S. K. (2014). Determinants of Household Savings in India: An Empirical Analysis Using ARDL Approach. Economics Research International, 18. Retrieved from: http://dx.doi.org/10.1155/2014/454675.

Schultz, T. P. (2004). Demographic Determinants of Savings: Estimating and Interpreting the Aggregate Association in Asia. Economic Growth Center Discussion Paper No. 901. Retrieved from: http://ssrn.com/abstract=639187.

Shumaker, L. D., \& Clark, R. L. (1992). Population Dependency Rates and Savings Rates: Stability of Estimates. Economic Development and Cultural Change, 40(2), 319-332.

Shorrocks, A. F. (1982). Inequality decomposition by factor components. Econometrica, 50(1), 193-211.

Thornton, J. (2001). Age Structure and the Personal Savings Rate in the United States, 1956-1995. Southern Economic Journal, 68(1).

Uremadu, S. O. (2009). The Impact of Macroeconomic and Demographic Factors on Savings Mobilisation in Nigeria. African Review of Money Finance and Banking, 23-49.

Yasin, J. (2008). Demographic Structure and Private Savings: Some Evidence from Emerging Markets. African Review of Money Finance and Banking, 7-21. 


\section{Appendix}

Table A1. Correlation matrix of the study variables

\begin{tabular}{|c|c|c|c|c|c|c|c|c|c|c|c|c|c|c|c|c|c|c|}
\hline & $\begin{array}{l}\text { Log } \\
\text { PCS }\end{array}$ & $\begin{array}{l}\text { Log } \\
\text { WAR }\end{array}$ & SSE & Gov. & $\begin{array}{l}\text { wealt } \\
\mathrm{h}\end{array}$ & $\begin{array}{l}\text { Farm } \\
\text { GSDP }\end{array}$ & $\begin{array}{l}\mathrm{F}_{-} \\
\text {head }\end{array}$ & $\begin{array}{l}\text { R_inf } \\
\text { lat. }\end{array}$ & $\begin{array}{l}\text { U_inf } \\
\text { lat }\end{array}$ & $\begin{array}{l}\text { MPC } \\
\text { E }\end{array}$ & Lit. & Post & Bank & GDI & GEM & LE & PCY & $\begin{array}{l}\mathrm{Gr} \\
\mathrm{PCY}\end{array}$ \\
\hline Log PCS & 1.00 & & & & & & & & & & & & & & & & & \\
\hline $\begin{array}{l}\text { Log } \\
\text { WAR }\end{array}$ & 0.70 & 1.00 & & & & & & & & & & & & & & & & \\
\hline SSE & 0.48 & 0.25 & 1.00 & & & & & & & & & & & & & & & \\
\hline Gov. & 0.32 & 0.64 & -0.21 & 1.00 & & & & & & & & & & & & & & \\
\hline wealth & -0.05 & -0.32 & 0.50 & -0.71 & 1.00 & & & & & & & & & & & & & \\
\hline $\begin{array}{l}\text { Farm } \\
\text { GSDP }\end{array}$ & -0.48 & -0.65 & -0.07 & -0.43 & 0.16 & 1.00 & & & & & & & & & & & & \\
\hline F_head & 0.05 & 0.04 & 0.25 & -0.04 & 0.01 & -0.07 & 1.00 & & & & & & & & & & & \\
\hline R_inflat. & 0.52 & 0.47 & 0.31 & 0.16 & -0.06 & -0.41 & 0.19 & 1.00 & & & & & & & & & & \\
\hline U_inflat. & -0.38 & -0.46 & -0.18 & -0.42 & 0.50 & 0.29 & -0.24 & -0.22 & 1.00 & & & & & & & & & \\
\hline MPCE & 0.52 & 0.65 & -0.16 & 0.82 & -0.76 & -0.48 & 0.09 & 0.28 & -0.62 & 1.00 & & & & & & & & \\
\hline Literacy & 0.57 & 0.78 & 0.03 & 0.65 & -0.43 & -0.69 & 0.19 & 0.36 & -0.53 & 0.75 & 1.00 & & & & & & & \\
\hline Post & 0.31 & -0.05 & 0.16 & -0.13 & 0.30 & -0.07 & -0.42 & 0.19 & 0.07 & -0.02 & -0.13 & 1.00 & & & & & & \\
\hline Bank & 0.74 & 0.71 & 0.24 & 0.56 & -0.45 & -0.41 & 0.26 & 0.55 & -0.53 & 0.72 & 0.66 & -0.05 & 1.00 & & & & & \\
\hline GDI & 0.47 & 0.78 & 0.16 & 0.78 & -0.42 & -0.52 & 0.04 & 0.23 & -0.52 & 0.67 & 0.82 & -0.17 & 0.57 & 1.00 & & & & \\
\hline GEM & 0.70 & 0.71 & 0.28 & 0.60 & -0.45 & -0.41 & 0.15 & 0.33 & -0.58 & 0.69 & 0.64 & 0.08 & 0.77 & 0.67 & 1.00 & & & \\
\hline LE & 0.70 & 0.67 & 0.21 & 0.51 & -0.29 & -0.53 & 0.39 & 0.46 & -0.54 & 0.72 & 0.73 & 0.09 & 0.71 & 0.58 & 0.66 & 1.00 & & \\
\hline PCY & 0.90 & 0.82 & 0.46 & 0.50 & -0.19 & -0.62 & 0.00 & 0.60 & -0.56 & 0.62 & 0.70 & 0.25 & 0.80 & 0.66 & 0.80 & 0.72 & 1.00 & \\
\hline GrPCY & 0.63 & 0.43 & 0.60 & 0.22 & 0.23 & -0.22 & -0.15 & 0.26 & -0.18 & 0.20 & 0.42 & 0.39 & 0.35 & 0.50 & 0.49 & 0.42 & 0.66 & 1.00 \\
\hline
\end{tabular}

Note: PCS stands for Per capita private savings; WAR, working-age ratio; SSE, social sector expenditure; Gov., governance index; Wealth, wealth inequality;

F_head, female headed households; R_inflat., rural inflation; U_inflat., urban inflation; Bank, bank density; GDI, gender development index; GEM, gender empowerment measure; LE, life expectancy; PCY, per capita income; GrPCY, growth in per capita income. 
Table A2. Pooled OLS regression-based decomposition of inequality in per capita private savings Dependent variable: Log of per capita gross private small saving collections in post offices and banks

\begin{tabular}{|c|c|c|c|c|}
\hline & (1) & $(2)$ & (3) & (4) \\
\hline \multirow[t]{2}{*}{ Log working-age ratio } & $6.083^{*}$ & $5.050 *$ & $5.326 *$ & $5.756 * *$ \\
\hline & (3.289) & $(2.468)$ & $(2.883)$ & $(2.723)$ \\
\hline \multirow[t]{2}{*}{ Log life expectancy } & & 4.221 & & \\
\hline & & (3.069) & & \\
\hline \multirow[t]{2}{*}{ Log literacy rate } & 1.932 & & & \\
\hline & $(1.565)$ & & & \\
\hline \multirow[t]{2}{*}{ Gender development index } & & & & 0.158 \\
\hline & & & & $(2.666)$ \\
\hline \multirow[t]{2}{*}{ Gender empowerment measure } & & & $4.732 * *$ & \\
\hline & & & $(2.240)$ & \\
\hline \multirow[t]{2}{*}{ Social sector expenditure } & $0.0639 * *$ & $0.0698 * *$ & $0.0497^{*}$ & 0.0319 \\
\hline & $(0.0293)$ & $(0.0274)$ & $(0.0247)$ & $(0.0312)$ \\
\hline \multirow[t]{2}{*}{ Governance index } & & & & -0.771 \\
\hline & & & & $(1.656)$ \\
\hline \multirow[t]{2}{*}{ Wealth inequality } & & & & 0.141 \\
\hline & & & & $(0.282)$ \\
\hline \multirow[t]{2}{*}{ Farm GSDP share } & & & -0.0062 & \\
\hline & & & $(0.0209)$ & \\
\hline \multirow[t]{2}{*}{ Female headed households } & 0.00480 & & & \\
\hline & $(0.0301)$ & & & \\
\hline \multirow[t]{2}{*}{ Rural inflation } & 0.0365 & 0.0265 & 0.0494 & \\
\hline & $(0.0562)$ & $(0.0496)$ & $(0.0510)$ & \\
\hline \multirow[t]{2}{*}{ Urban inflation } & -0.00561 & & & \\
\hline & $(0.103)$ & & & \\
\hline \multirow[t]{2}{*}{ Log mean MPCE } & & 0.725 & & \\
\hline & & $(0.768)$ & & \\
\hline \multirow[t]{2}{*}{ Bank density } & & & & $12.13 * * *$ \\
\hline & & & & (3.492) \\
\hline \multirow[t]{2}{*}{ Post office density } & $0.700 * *$ & $0.555^{* *}$ & $0.535 * *$ & $0.663 * * *$ \\
\hline & $(0.312)$ & $(0.240)$ & $(0.252)$ & $(0.232)$ \\
\hline \multirow[t]{2}{*}{ Constant } & $-32.58 * * *$ & $-41.42 * * *$ & $-22.04 *$ & $-23.26 * *$ \\
\hline & $(10.94)$ & $(11.53)$ & $(12.08)$ & $(10.16)$ \\
\hline Observations & 32 & 32 & 32 & 32 \\
\hline R-squared & 0.71 & 0.75 & 0.73 & 0.80 \\
\hline Adjusted R-squared & 0.63 & 0.69 & 0.67 & 0.74 \\
\hline
\end{tabular}

